\title{
A Study Of Feminist Ehical Dimensions In Jai Nimbkar's Come Rain
}

\author{
Dr. Sujata Bamane \\ Associate Professor,Head, Dept. of English \\ Fergusson College (Autonomous),Savitribai Phule Pune University \\ Pune, Maharashtra, India.
}

\begin{abstract}
Ethical discourse is a manifestation of masculine perspective. However, woman-centric approach to ethics is known as Feminist Ethics. It addresses to the subservient position of woman against man's dominating one. The present paper offers a study of Ann, a female protagonist in Jai Nimbkar's novel, Come Rain (1993). It aims at studying a character of Ann projected as an 'idealistic and rather unconventional American girl' exploring an inner and outer space in her 'stormy relationship with her Indian husband and his family'. The novel focuses on the patterns of male-domination and woman's struggle for her liberation from the rigid norms of Indian society. It too is an investigation of whether moral reasoning based on the feminist Care and justice ethics can offer solace to Ann's logical state of mind? Can she by the end of the novel exist as an independent individual entity? To what extent does Jai Nimbkar keep her story engaged with feminist ethical concerns to offer equal rights to woman and achieve a balanced picture of society? and so on.
\end{abstract}

Keywords: Ethics, Feminist ethics, liberation, male-domination, moral-reasoning, Subservient.

Ethics is branch of philosophy and a discourse that sets the principle of morality for human beings. Right from the ancient, Greek era, ethicists have theorised the ethical system in various fields. Hence the views on ethical behaviour in various fields varies from country to country, religion to religion, time to time and gender wise too. It is defined as 'the rules of conduct recognized in respect to a particular group, culture etc.' (dictionary.reference.com) In an attempt to resolve the questions of human morality in general, the term 'Ethics' was looked upon by various ideologists and ethicists in particular. With the rise of women liberation movement during 1960s, the feminist writers addressed the gender-based idea of morality and developed earlier feminine 'ethics of care' to 'ethics of justice.' Hence the present paper aims at studying the woman-centric approach to ethical discourse which has been a manifestation of masculine perspective. Carol Gilligan, a Harvard psychologist observes that men and women differ while dealing with moral issues. Leslie M. Dawson summarizes Carol Gilligan's research on ethical conduct in her article, Women and Men Morality and Ethics,

Men she contends are likely to consider moral issues in terms of justice, rules and individual rights. Women on the other hand, tend to consider such issues in terms of relationships, caring and compassion. (www.homepages.se.edu/... /files/...Women and Men-Morality-andEthics.pdf)

Hence the 'ethic of care' promoted in the patriarchally constructed feminine world was looked upon as one of the inborn virtues of woman, needed for social and moral transformation. Caring as an ethical action was reinforced by woman's position of 'motherhood', 'wifehood' and 
'womanhood', which further reduced her to the secondary position. Jane Scoular in her article, Feminist Jurisprudence (2011:69) refers one of the scholars, Smart Carol, who describes "the process of fixing 'womanhood' as 'rapable, vulnerable and victimizable' which sanctions regulation and control." The subservient status of women caused the emergence of feminist ethical theory as a concern for 'female oppression' and 'female lives'. Conventionally treated as feminine, 'caring' as an ethical action remained as 'one of the central insights of feminist thought.' Further Claudia Card in her writing on 'Ethics, Feminist' (2000:179) elaborates feminists' engagement with 'care ethic' embodies the values of justice and rights and ensures a step to "nourish female vitality, resist oppression, overcome past oppression, facilitate healthy bonding and develop sound relations with larger environments." The emergence of feminist ethics with its various dimensions is genuine response to the need of unbiased gender treatment as according to Claudia Card (2000:179) 'it envisions better alternatives, better relations and social transformations.' In her study on 'Ethics and Feminist' she shares the views of the philosophers like Virginia Held, Iris Young and Maria Lugone. (2000:181)

Despite the no. of disagreements about 'justice' by the advocates of feminist care ethics, one philosopher, Virginia Held finds 'justice' 'indispensable' and insists that it 'needs to be supplemented by care'. In a view of Marxian political philosopher, Iris Young 'a theory of justice' centres on decision making, divisions of labour and culture'. It is further supported by Maria Lugone, the Argentinian philosopher with her concept of 'world-travelling' which facilitates both 'justice and care' as a direction for women's collective resistance to their exploitation. Thus, among the various traditions of feminist ethics, 'feminist care ethics' appears to be the major one as it gets strengthened with its advocacy of 'justice ethics'. Hence the present paper aims at studying the role of both the feminist ethics in bridging the gap between 'identity' and the process of 'identification' without which the discussion of feminist ethical dimensions stands invalid. In her debate on feminism, Denise Riley, a famous feminist thinker describes the term 'identity' as an 'acutely double-edged weapon'. The process of 'resistance' to the exploitation goes in parallel to the process of 'subjectification' which according to Riley can acute the sufferings of woman. Hence it is true what Gilligan Carol observes about vulnerability of everyone 'both to oppression and abandonment' and recurrence of 'two moral visions- one of justice and one of care in human experience.'

Jai Nimbkar, one of the modern Indian woman novelists under study is known for her expression of feminist sensibility in her writings. She has three famous novels viz. Temporary Answers, Joint Venture and Come Rain to her credits. In her third novel, Come Rain, Jai Nimbkar projects an 'idealistic and rather unconventional American girl exploring an inner and outer space in her 'stormy relationship with her Indian husband and his family'. Nimbkar in a very skilful manner captures the 'subtle nuances of interpersonal relationships' and allows her female protagonist, Ann to explore her identity. In her attempt to adjust herself in a new country with unfamiliar people and culture around she vascilitates between Indian and American way of life. Her encounter with the people 'firmly rooted in social reality' leaves her with a strong feeling of an 'outsider'. Thus, Jai Nimbkar with her limited no. of literary legacy emerges as a writer, who with the universal qualities of her female characterbuilds her 'fictional universe' as Ann is portrayed speaking from 'within and against'.

In its major thrust on the patriarchal notion, traditional ethics strengthens the 'dominant class structure' and causes the diminution of the position of women. Hence, the feminist philosopher, Alison Jaggar tries to reformulate the traditional ethics in five different ways necessary for harmonious society. (www.plato.stantford.edu) 


\section{'Traditional Ethics shows less concern for women's opposed to men's issues and interests.'}

The discourse of marriage in the Indian context empowers the position of one and disapproves others' at the same time. Ann, a newly married American wife of Ravi, an Indian husband is the victim of the same. But Jai Nimbkar sketches her character as a 'moral agent' with logical thinking. Her transition into a new world after marriage leaves her feeling 'neither elation nor disappointment'. The controlling group culture of Ravi's family acknowledges Ann's entry as a newly married woman with the 'complete absence of welcoming warmth.' Her greeting to her mother-in-law is reciprocated with her 'a long openly appraising look'. Ravi too joins by legitimating the instrumentalised power of his mother while introducing his wife, Ann. On the other hand, Ravi's re-entry is made special with warm Indian traditional manner. He is honoured with 'vermillion on his forehead and waved a lamp around in front of him.' (CR, p-6) However, readers are made aware that 'He (Ravi) had with ease made the transition into a world to which she had as yet no access.' (CR, p-4) Consequently, Ann is left with a feeling of 'left out' and 'neglected wife' as Ravi doesn't make her assimilation with his family easy. To add to it Ravi shocks Ann by dismissing her 'legitimate grievance' as 'an inconsequential and irrational wifely gripe.' (CR, p-1) Ravi's representation of traditional ethics is hit to certain extent when Ann calls him, 'being intentionally obtuse'.

The novel, Come Rain projects Mrs. Gogte, Ravi's mother as a product of male dominated society that promotes the traditional ethics with less concern to women's issues. As a matter of fact she shows less concern for Ann's food habits and her stomach problems aggravating due to spicy food. In a very stern manner she replies to her demand of bland food, 'Are we all supposed to change our eating habits and eat what we don't like for the sake of one person?' (CR, p-31) However, Ann's reaction against Ravi's overvaluing Indian food lacking even animal protein does reflect her feminist ethical manner. Her initiative of making coffee too receives a loud grumble by Mrs. Gogte which further extends towards Ann's complete humiliation. She expresses her resentment in bitter words to her son, 'Overnight you forget all that I did for you and can be rude to me for the sake of this white-faced monkey.' (CR, p-33) Ravi too in his reaction indirectly shares his perception of Ann 'being a hypochondriac'. In her reaction to the whole scenario Ann looks for a solution in eating biscuits in private. Also she seeks some satisfaction in her father-in-law's taking a note of her less appetite.

\section{Secondly, 'the need to reformulate the traditional ethics is that the traditional ethics views as trivial woman's housework, caring children, elders etc.'}

Ann's encounter with Mohini, Ravi's sister and her lack of future vision leaves Ann amazed and worried. Ravi is depicted as a person who builds future plans based on certain assumptions. Whereas, Ann appears to be a responsible person with 'free will'. Hence she cares for Mohini and later on supports her decision of marrying PremShivdasani, an outcaste. However, Ravi due to his extremely preconceived notions of decisive girl gets annoyed and underrates Ann's caring for Mohini against his parents' wish as an act done 'in a crusading spirit and not because she felt anything for Mohini.' (CR, p-105) For him it is her 'inexcusable interference' (CR, p-02). Her caring for Mohini can be looked upon as a virtuous ethical action which further is extended with her justice ethical stand. Her pertinent reply to Ravi and his family's notion of 'wifehood' maintains the balance between feminist 'care' ethics and 'justice' ethics. She asserts, 'You can tell your father that a wife is a human being, not a thing to be controlled and ordered about. And I shall damn well poke my nose into Mohini's affairs, with her permission.' (CR, p-103)

Ravi in his advocacy of tradition ethics views Ann's doing job and looking after household work with contempt. While devaluing her contribution once he says, 
'... Going into business for yourself is not quite like doing a job. You can't just work eight to four and then come home and forget about it. It's a constant responsibility.' (CR, p-219)

Despite his resentment and 'ungracious tone' Ann initiates to reach out. However, her intransigent behaviour is looked upon with disdain. The household chores and the duty of raising children is considered to be exclusively woman's share. Ravi measures woman's selfrespect in her engagement with 'shopping, cooking, looking after baby ...' (CR, p-255) He demonstrates his 'fastidiousness' towards his son, Rahul. He says, 'Why is he so filthy? Look, call him to you, will you? He is making a mess of my clothes.' (CR, p-214) To which Ann replies with logical reasoning and reminds him of his childhood days and explains children being 'incapable of understanding the concepts of dirty and clean.' (CR, p-214)

Hence, Ann is seen emerging with a faith of re-establishing harmony in the available scenario.

\section{'Thirdly, the traditional ethics implies that in general women are not morally mature or deep as men.'}

'Freedom is one of the conditions of moral behaviour.' states H.M. Joshi (2000: p-4) in his writing, Traditional and Contemporary Ethics. Jai Nimbkar articulates genuinely a double female consciousness. In case of Ann we find her suffering firstly from her being foreigner and secondly, being woman. Her reception by Sangampur people underpins the fact that:

'To them she was not a person to be explored, understood, responded to, but only an adjunct to Ravi, to be looked at, sized up and then relegated to the background.' (CR, p-12)

Ann stands firmly regarding her identity and replies assertively, 'I am not an outsider, strictly speaking.' (CR, p-12) It does bother her to see Ravi's lack of understanding that one cannot be happy if one is treated as an outcaste. Ann develops a sense displacement when Ravi says, 'I didn't know you were so unhappy here.' (CR, p-59)

It is said that taking responsibility for voicing one's own voice makes one's own existence worth. However, in case of Mrs. Gogte it proves to be the other way round as in her attempt to stamp her existence, she outrages at Ann's proposal of 'setting up a separate house' and fails to achieve a level of maturity. She goes to an extend and blames her son, Ravi for his acting like her foreign wife's 'pet cats'. On the other hand, Mr. Gogte interrogates with her and comes up with an ethical judgement, 'What can people say? They are ready to talk no matter what happens. Why should you pay attention to them?' (CR, p-59) The matter ends with Ann's 'distinctive moral voice' which, according to Gilligan speaks 'a language' of 'care' and of 'justice'. Despite her mother-in-law's 'unbending stance' she decides to set up a separate house and refuses to 'stand being under obligation'. The decision does justice to her legitimate demand of 'a room of one's own' and ends her state of being subservient. At the same time, she tries to take care of family relations though distant yet healthy as she believes, 'Getting together has to be a conscious act of will.' (CR, p-4) A close view of the character of Ann gives one an understanding that woman does have a capacity of moral reasoning against man's being judgemental. For instance, Ann shocks Ravi with her logical explanation to his indifference in Mohini's matter. She says, 'Even if you feel that Mohini is making a terrible mistake, all you can legitimately do is try to dissuade her. It is unethical to try to browbeat or terrorize or blackmail her into submission.' (CR, p-104) Further she strongly emphasizes her belief in an 'independence of an adult' and 'responsibility even if it is with calamitous results.' It can be looked upon as a blow of 'feminist moral reasoning' to Ravi's judgmental statement. 
'Fourthly, traditional ethicsoverrates culturally masculine traits like "independence, autonomy, intellect, will, wariness, hierarchy, domination, culture,transcendence, product, asceticism, war, and death," while itunderrates culturally feminine traits like "interdependence,community, connection, sharing, emotion, body, trust, absence ofhierarchy, nature, immanence, process, joy, peace, and life.'

Gradually, Ann is exposed to several angles of a 'petty power politics of family'. She observes the way Mr. Gogte, Ravi's father carries his authority is a sign of well-established dominant power structure. The very next day of her arrival in India, she has an encounter with her imperious father-in-law. He is described as

'an imposing looking man, tall and heavy .... His voice was that of a man used to command and his manner that of one used to arranging and directing the lives of those around him. He Carried his authority easily and its exercise was casual and relaxed as though he did not expect opposition.' (CR, p-5)

Mahesh, Ravi's brother is the victim of his parental authority. While sharing his grudges with Ann, he says, '... He just likes to control everything. He wouldn't let go his authority.' (CR, p-44) However, ironically, he too becomes a part of this 'authoritarian repressive' system promoted by his mother and denies Ann's entry in their family. The periscopic view of the novel makes one understand that Ann not only fights for her rights and her self-respect but she also reacts on the victimized condition of Mahesh. She is the witness of his predicament. Hence, she is shown marveling at the 'equanimity with which Mahesh went on working under controls he resented, refusing to assert his independence, his right to share in decision-making or the handling of money.' (CR, p-43)

The hierarchical structure in India offers son a privilege of share in an ancestral property. Ravi too is favored with this structure hence develops flabby personality. On the other hand, being rational, Ann finds their talk on financial independence going always on a diverse wavelength. Though traditional ethics overrates culturally masculine traits like hierarchy, independence, domination and so on, Ann finds them withering out in the real sense as Ravi fails to achieve a real 'masculine appeal'. For instance, Ravi's being casual regarding financial independence is the result of the truth of his ancestral wealth. It reflects in his reply to Ann, '... Anyhow, all this is ancestral wealth, so we all have a legitimate share in it. It's not as though I am a charity case.' (CR, p-24) It completely stands in contrast to what Ann feels, '... But it just goes against my grain to be under financial obligation to anyone.' (CR, p-24) Mr. Gogte though carries his authority, hardly he exercises it in the domestic sphere. Consequently, Ann has to confront power hierarchies represented by Mrs. Gogte through her 'directness of manners'. (CR, p-156) Ravi's mother exercises her role of leadership not through 'direct coercion' but by indirect manner. Hers can be looked upon as 'hegemonic control'. It becomes obvious several times like at the time of Ann's entry in her family or at the time of her initiative for cooking less spicy food separately or for learning Marathi. In short, her in-laws are looking for power and she for independence even if meant 'self-destruction'.

\section{Finally, 'traditional ethics favors 'male' ways of moral reasoning that emphasize rules, universality and impartiality over 'female' ways of moral reasoning that emphasize relationship, responsibilities, particularity and partiality.'}

Ravi's mother, who is a product of male-governing society advocates the patriarchal repressive system as it gives her scope of ruling over other subordinate members in family. Naturally, traditional ethics favours her 'male way of moral reasoning that emphasizes rules and rights'. She appears to be 'cold and unforgiving mother', who rules her household with an iron will'. Against the background of Ravi's rejecting Usha's marriage proposal Ann views Mrs. Gogte's 
inhuman way of using her 'position to badger (her) children into submission.' (CR, p-55) It disappoints her to see Usha accepting life with 'equanimity'. Ann further simply is aghast to see her mother-in-law exercising right to object Mr. Gogte's being generous with her regarding the matter of her Marathi tuition when she registers her hostility and asks her son, Ravi, 'What does she need a tuition for? Isn't it enough that we all talk to her in Marathi?' (CR, p-23) Ann is mature enough to perceive her mother-in-law's authoritative tone as merely a gain of her status as a wife of Mr. Gogte and her way of moral reasoning reflecting her partial behaviour. She draws Ravi's attention to his mother's condescending treatment. She says, 'All the difference in the world, because if your father is paying for it, that gives your mother the right to gripe about it.' (CR, p-23)

The echoes of husband's 'coercive' vilification of his wife's mother is a pre-approved angle of patriarchal structure. Ravi's male-cantered 'binary logic' outrages Ann as it makes obvious the discrimination between her mother and his mother. His being accusive about her mother by calling her 'ignorant and provincial' is returned with Ann's ethical response. She emphatically validates her experience under his mother's justified atrocious behaviour. However, despite his illogical judgement, Ann takes an effort to 'restore the harmony' which ultimately is sidelined by Ravi by 'marking out an area of non-communication'. Consequently, Ann in her response to his sole decision of walking out on her 'went to the door at a run, shot the bolts with decisive loud clicks, like a full stop to something.' (CR, p- 261) She strongly refuses the assumption that husband is a 'lord and master' of wife. She declares her decision to her mother-in-law, 'Thank you, Aai. I appreciate your offer, but I would really rather be independent.' (CR, p-266)

What is appreciative about Jai Nimbkar as a writer is the projection of her 'nurturant perceptions of women' (Ann R. Jones, 1985:93) as she maintains her heroine's spirit of 'selfgovernance'. In the end of the novel, in her response to injustice her heroine resists the patriarchal notion of 'care' and 'justice' ethics. Her feminist ethical perspective elevates her status from 'other' to a distinctive 'moral agent'. She promotes moving out of the male-oriented ideologies and celebrates her heroine's refraining from the passive participant of this hierarchy to the creator of the 'new female discourses'. The relationship between the feminine logic/discourse and masculine logic/discourse is well summarized by Luce Irigarary, a French writer and quoted by Ann Jones (1985:89):

Contradictory words seem a little crazy to the logic of reason and inaudible for him who listens with readymade grids, a code prepared in advance. In her statements- at least when she dares to speak out- woman retouches herself constantly.

Hence Jai Nimbkar's woman stands as different from man rather than opposite to man.

\section{References}

Card, C. (2000). Ethics Feminist. Encyclopaedia of Feminist Theories. Ed. Lorraine Code. Routledge: London \& New York.

Jones. A. (1985:87). Writing the body: toward an understanding of I'ecriture feminine. Feminist Criticism and Social Change ed. By Judith Newton and Deborah Rosenfelt. Methuen: New York and London.

Joshi, H.M. (2000). Traditional \& Contemporary Ethics: Western and Indian. Bhartiya Vidya Prakashan: Delhi. Nimbkar, J. (1993). Come Rain. Orient Longman Ltd: Bombay.

Scoular, J. (2011). Feminist Jurisprudence. Contemporary Feminist Theories. Ed. Stevi Jackson and Jackie Jones: Jaipur. (Reprint) 


\section{WEB SOURCES}

wwW.questia.com

www.plato.stantford.edu/entries/feminism-ethics/

www.dictionary.references.com

www.homepages.se.edu/...files/...womenandmenmorality-and-ethics 